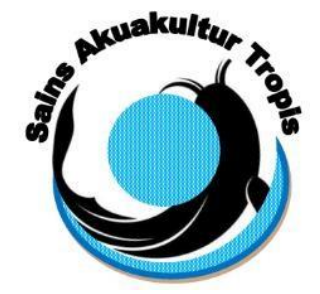

\author{
Jurnal Sains Akuakultur Tropis \\ De p a r t e m e n A u a $k$ u t u r \\ Fakultas Perikanan dan IImu Kelautan - Universitas Diponegoro \\ JI. Prof. Soedarto, SH, Tembalang, Semarang 50275 \\ Telp. (024) 7474698, Fax.: (024) 7474698 \\ Email: sainsakuakulturtropis@gmail.com, sainsakuakulturtropis@undip.ac.id
}

\title{
PENGARUH EKSTRAK BAWANG PUTIH (Allium sativum) TERHADAP TINGKAT PENCEGAHAN INFEKSI BAKTERI Vibrio harveyi DAN KELULUSHIDUPAN IKAN NILA SALIN (Oreochromis niloticus)
}

\author{
The Effect of Garlic Extract (Allium sativum) on the Prevention Level of Vibrio Harveyi \\ Bacterial Infection and the Survival Rate of Saline Tilapia (Oreochromis Niloticus) \\ Raynol Simorangkir, Sarjito*), A. H. Condro Haditomo \\ Departemen Akuakultur \\ Jurusan Perikanan Fakultas Perikanan dan Ilmu Kelautan \\ Universitas Diponegoro J1. Prof. Soedarto Tembalang, Semarang, Jawa Tengah-50275
}

\begin{abstract}
ABSTRAK
Vibrio harveyi merupakan salah satu agen pembawa penyakit vibriosis yang menjadi penyebab kematian masal dalam budidaya ikan bersalinitas baik pembenihan maupun pembesaran. Bawang putih (Allium sativum) sebagai salah satu tanaman obat terbukti memiliki aktivitas antibakteri terhadap spektrum luas bakteri Gram positif maupun Gram negatif, sehingga berpotensi dijadikan antibiotik alami. Penelitian ini bertujuan untuk mengkaji pengaruh penambahan ekstrak bawang putih (A. sativum) pada pakan terhadap kelulushidupan ikan nila salin (Oreochromis niloticus) yang diinfeksi oleh bakteri V.harveyi. Penelitian dilakukan dengan metode eksperiman menggunakan Rancangan Acak Lengkap (RAL) dengan 4 perlakuan dan 3 ulangan. Parameter yang diamati yaitu kelulushidupan (survival rate/SR), total leukosit, dan gejala klinis secara morfologi ikan nila salin yang diinfeksi bakteri V.harveyi. Total ikan uji sebanyak 120 ekor dengan panjang rata-rata $\pm 10 \mathrm{~cm}$. Perlakuan yang diberikan yaitu A (0 ppm), B (50 ppm), C (100 ppm), dan D (150 ppm) didapat berdasarkan hasil uji pendahuluan berupa uji zona hambat. Pergantian air dilakukan setiap 3 kali sehari sebanyak 30\% dari air pemeliharaan selama 14 hari. Hasil penelitian menunjukkan bahwa penambahan ekstrak bawang puith berpengaruh nyata terhadap kelulushidupan $(\mathrm{p}<0,05)$. Perlakuan D $(150 \mathrm{ppm})$ menunjukkan kelangsungan hidup tertinggi $(68,15 \%)$, diikuti perlakuan C $(66,67 \%)$, B $(62,96 \%)$ dan A $(48,15 \%)$. Konsentrasi terbaik ditunjukkan oleh perlakuan D yaitu 150 ppm.
\end{abstract}

Kata Kunci: bawang putih (Allium sativum), nila salin (Oreochromis niloticus), Vibrio harveyi, kelulushidupan, respon imun

\section{ABSTRACT}

Vibrio harveyi is one of the carriers of vibriosis disease which is a cause of mass death in maternity and aquaculture both hatchery and enlargement. Garlic (Allium sativum) as one of the medicinal plants has been shown to have antibacterial activity against the broad spectrum of Gram positive and Gram negative bacteria, so that it has the potential to be used as a natural antibiotic. This study aims to examine the content of garlic extract (A. sativum) in feed on the survival of saline tilapia (Oreochromis niloticus) which is infected by V.harveyi bacteria. The research was conducted using the experimental method with Completely Randomized Design (CRD) with 4 treatments and 3 replications. Parameters observed was survival rate (SR), total leukocytes, and morphologically clinical symptoms of saline tilapia infected with V.harveyi bacteria. The total test fish was 120 tails with an average length of $\pm 10 \mathrm{~cm}$. . The treatments given were A $(0 \mathrm{ppm}), B(50 \mathrm{ppm}), C(100 \mathrm{ppm})$, and D (150 ppm) obtained based on the results of the preliminary test in the form of a inhibitory zone test. Water exchange were carried out every 3 days 30\% of the rearing water for 14 days. The results of the study prove the existence of realistic garlic 
extracts for survival $(p<0.05)$. Treatment $D(150 \mathrm{ppm})$ showed the highest survival $(68.15 \%)$, followed by treatment $C(66.67 \%), B(62.96 \%)$ and $A(48.15 \%)$. The best concentration is shown by treatment $D$, which is 150 ppm.

Keyword: garlic (Allium sativum), Saline Tilapia (Oreochromis Niloticus), Vibrio harveyi, survival rate, immune respons

\section{PENDAHULUAN}

Pengembangan ikan nila unggul yang dapat hidup di perairan dengan salinitas tinggi yang disebut ikan nila salin yang mampu berkembang dan tumbuh di perairan payau dengan kadar garam lebih dari 20 ppt atau bahkan di perairan laut dengan salinitas hingga 32 ppt melalui pemanfaatan karakter euryhaline yang dimiliki ikan nila. Pengembangan budidaya ikan nila di perairan payau (brackishwater) dan perairan dengan salinitas tinggi sudah menjadi perhatian dilingkup budidaya (Jalaluddin, 2014). Pengembangan budidaya ikan nila di perairan payau (brackishwater) dan perairan dengan salinitas tinggi sudah menjadi perhatian dilingkup budidaya. Salah satu kendala usaha budidaya ikan nila adalah perubahan lingkungan lahan budidaya akibat tingginya pencemaran dan kesalahan penanganan budidaya antara lain kurang efisiennya penggunaan pakan sehingga memicu timbulnya masalah penyakit. Penyakit vibriosis disebabkan oleh beberapa jenis bakteri vibrio seperti: Vibrio harveyi, V. parahaemolyticus, V. alginolyticus, V. fischeri. Bakteri V.harveyi merupakan jenis Vibrio yang paling berbahaya diantara jenis lainnya (Muliani et al. 2015).

Penanganan penyakit selama ini dilakukan dengan menggunakan antibiotik. Penggunaan antibiotik untuk pengobatan penyakit pada hewan air secara berlebihan dapat menimbulkan resistensi terhadap bakteri patogen dan menghasilkan residu antibiotik dalam produk akuakultur yang merupakan ancaman bagi kesehatan ikan. Oleh karena itu, diperlukan alternatif pengobatan menggunakan antibiotik yang bersifat hayati agar lebih ramah lingkungan. Maka dilakukan suatu pencegahan dengan bahan-bahan alami yang aman dan ramah lingkungan yaitu bawang putih (Allium sativum). Bawang putih diharapkan dapat menjadi obat alternatif untuk mengatasi pertumbuhan dari bakteri V.harveyi tersebut. Kandungan alisin dalam bawang putih dipercaya dapat membunuh bakteri gram positif maupun gram negatif. Penelitian ini dilakukan sebagai salah satu langkah penemuan antibiotik alternatif alami dalam akuakultur khususnya budidaya ikan nila salin.

Tujuan dari penelitian ini adalah mengkaji pengaruh penambahan ekstrak bawang putih (A.sativum) terhadap kelulushidupan ikan nila salin yang diinfeksi bakteri V.harveyi. Hasil penelitian ini diharapkan dapat memberikan informasi, pengetahuan dan solusi kepada pembudidaya ikan nila salin dalam memilih bahan alami sebagai alternatif pengobatan vibriosis.

\section{MATERI DAN METODE}

Materi dalam penelitian ini meliputi ikan nila salin (O.niloticus) dengan panjang rata-rata $10 \mathrm{~cm}$ sebanyak 120 ekor (10 ekor/akuarium) yang dipelihara dalam 12 akuarium berukuran 30 x 40 x $38 \mathrm{~cm}$ berisi $10 \mathrm{~L}$ air pemeliharaan (10 ppt) dan diberi pakan pellet komersil secara at satiation setiap 2x sehari (08.00 dan 16.00). Isolat bakteri V.harveyi yang digunakan diperoleh dari Balai Perikanan Budidaya Air Payau (BPBAP) Situbondo. Adapun bawang putih (A. sativum) diperoleh dari daerah Semarang, Jawa Tengah. Penelitian dilaksanakan pada bulan Agustus - Oktober 2017 di laboratorium Kering Akuakultur, FPIK Semarang, Jawa Tengah.

\section{Metode}

Penelitian ini menggunakan metode eksperimental dengan rancangan acak lengkap (RAL) yang terdiri dari 4 perlakuan dan 3 ulangan. Perlakuan yang diujikan yaitu penambahan ekstrak bawang puith kedalam pakan komersil. Persiapan ekstrak bawang putih, diperoleh dari $1 \mathrm{~kg}$ bawang putih yang diekstrak dengan menggunakan metode maserasi, dimana metode maserasi merupakan metode perendaman bawang putih yang direndam dengan larutan etanol. Selanjutnya ekstrak bawang putih murni diencerkan dengan menggunakan larutan aquades untuk mendapatkan konsentrasi yang dinginkan. Perlakuan kultur bakteri V.harveyi dilakukan menggunakan media TSA (Trypticase Soya Agar). Sebelum digunakan bakteri terlebih dahulu dilakukan pasase. Perlakuan penambahan ekstrak bawang putih pada pakan diberikan pada awal mulai pemeliharaan hingga penginfeksian dengan bakteri V.harveyi yaitu selama 20 hari. Bakteri V.harveyi disuntikan dengan kepadatan $10^{8} \mathrm{CFUml}^{-1}$ sebanyak $5 \mathrm{ml} / \mathrm{ekor}$. Berdasarkan hasil uji pendahuluan berupa uji zona hambat, dimana hasil zona hambat menunjukkan diameter sebesar $5 \mathrm{~mm}$ untuk konsentrasi 150 ppm, maka konsentrasi tiap perlakuan yang dilakukan adalah A (0 ppm), B (50 ppm), C (100 ppm) dan D (150 ppm). Pergantian air dilakukan setiap 3 hari sekali sebanyak 30\% dari air perlakuan, diaerasi terus menerus dan kualitas air dicek pada awal, tengah dan akhir penelitian (Kongchum et al., 2016). Parameter yang diamati meliputi kelulushidupan (SR) ikan nila salin selama pemeliharaan 14 hari dan pasca 7 hari pemeliharaan setelah infeksi V.harveyi, total leukosit dan gejala klinis morfologi ikan nila salin yang terinfeksi bakteri V.harveyi. Data dianalisis menggunakan analisis sidik ragam (ANOVA single factor) selang kepercayaan 
yang digunakan adalah 95\%. Setelah dilakukan analisis ragam, apabila ditemukan perlakuan berbeda nyata $(\mathrm{p}<0,05)$, maka dilakukan pengujian untuk beda nyata jujur $(\mathrm{BNJ})$ menggunakan uji Duncan.

\section{Total Perhitungan Leukosit}

Untuk menghitung total leukosit, maka pertama-tama darah diambil sebanyak $1 \mathrm{ml}$ dimasukkan dalam eppendorf, selanjutnya sampel darah dimasukkan kedalam pipet thoma leukosit sampai skala 0,5 lalu ditambahkan larutan turk's sampai skala 11 pada pipet thoma leukosit. Larutan tersebut dihomogenkan dengan cara mengayunkan pipet thoma leukosit secara perlahan-lahan selama 15-30 detik. Selanjutnya larutan dibuang 1-2 tetes lalu tetesan berikutnya diteteskan pada sisi cover glass yang menutupi haemacytometer sehingga larutan akan menyebar menutupi permukaan haemocytometer. Penghitungan leukosit dilakukan dengan bantuan mikroskop pada pembesaran 10 kali. Jumlah sel leukosit yang dihitung diambil secara acak dari empat kotak.

\section{Kelulushidupan (SR)}

Kelulushidupan atau survival rate (SR) dihitung untuk mengetahui tingkat kematian udang uji selama penelitian, kelulushidupan dapat dihitung menggunakan rumus Effendie dan Tang (2002), sebagai berikut:

$$
\mathrm{SR}=\frac{\mathrm{Nt}}{\mathrm{N}_{0}} \times 100 \%
$$

Keterangan:

SR = Tingkat kelangsungan hidup (\%)

$\mathrm{Nt} \quad=$ Jumlah ikan yang hidup pada akhir pengamatan (ekor)

No = Jumlah ikan yang hidup pada uji tantang (ekor)

\section{Pengamatan Gejala Klinis}

Pengamatan abnormalitas ikan dicatat gejala klinisnya baik secara tingkah laku ikan amupun morfologi ikan selama penginfeksian, saat pemberian pakan dengan kandungan ekstrak bawang putih, dan selama pemeliharaan.

\section{HASIL DAN PEMBAHASAN}

HASIL

Total Perhitungan Leukosit

Hasil perhitungan total leukosit ikan nila salin (O.niliticus) selama penelitian dapat dilihat pada grafik yang tersaji pada Gambar 1 .

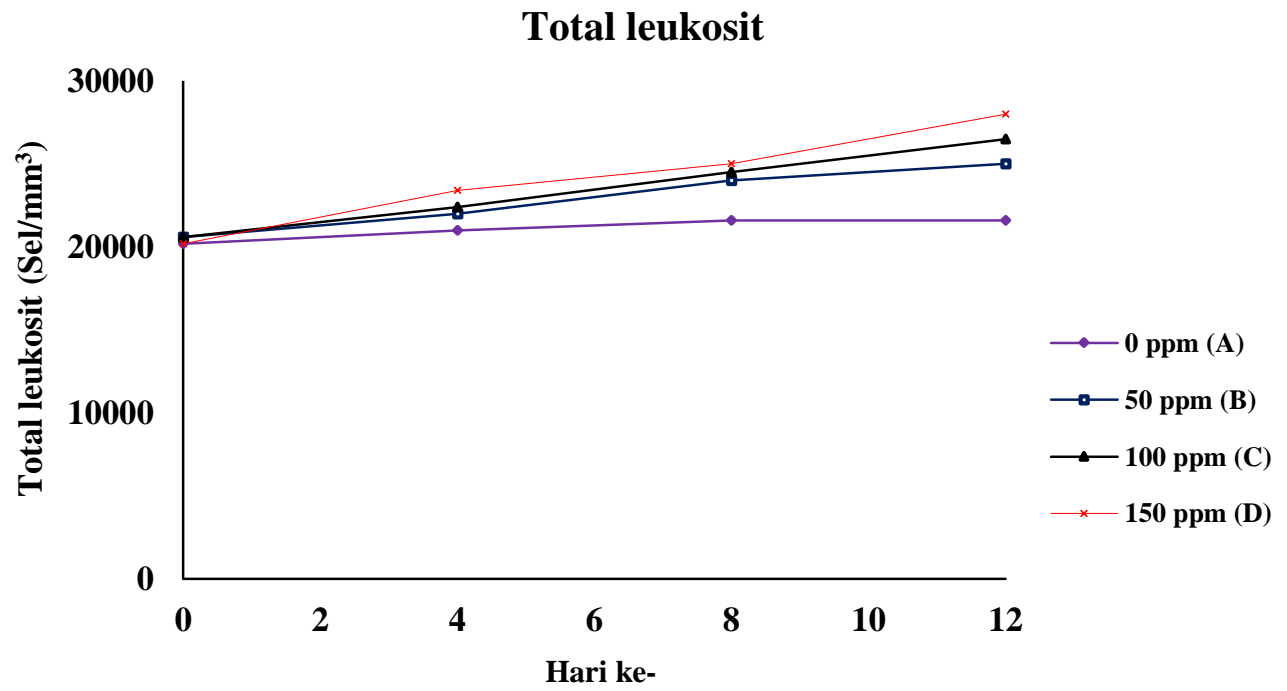

Gambar 1. Hasil perhitungan total leukosit ikan nila salin (O.niliticus) 
Dari hasil (Gambar 1), dengan penambahan ekstrak bawang putih pada pakan dapat memberikan efek peningkatan dari leukosit darah ikan. Total leukosit darah ikan yang tertinggi terlihat pada pakan yang ditambah oleh ekstrak bawang putih sebanyak 150 ppm. Penambahan ekstrak bawang putih sebanyak 50 ppm, pada akhir pengamatan total leukosit tidak memeberikan pengaruh yang nyata pada total leukosit darah ikan. Penghitungan total leukosit penting dilakukan untuk mengetahui status kesehatan ikan.

Kelulushidupan (SR) Tabel 1.

Tingkat kelulushidupan ikan nila salin (O.niloticus) sebelum uji tantang dan pasca uji tantang tersaji pada

Tabel 1. Hasil Tingkat kelulushidupan (SR) ikan nila salin

\begin{tabular}{lcc}
\hline \multirow{2}{*}{ Perlakuan } & \multicolumn{2}{c}{ Nilai Tingkat Kelushidupan (SR) (Rerata \pm SD) } \\
\cline { 2 - 3 } & Sebelum Uji Tantang & Pasca Uji Tantang \\
\hline A $(0 \mathrm{ppm})$ & $83,33 \pm 5,77^{\mathrm{a}}$ & $47,69 \pm 3,21^{\mathrm{a}}$ \\
B $(50 \mathrm{ppm})$ & $90,00 \pm 0,00^{\mathrm{b}}$ & $63,06 \pm 6,42^{\mathrm{b}}$ \\
C $(100 \mathrm{ppm})$ & $90,00 \pm 0,00^{\mathrm{b}}$ & $66,67 \pm 0,00^{\mathrm{b}}$ \\
D $(150 \mathrm{ppm})$ & $93,33 \pm 5,77^{\mathrm{b}}$ & $67,78 \pm 8,98^{\mathrm{b}}$ \\
\hline
\end{tabular}

Hasil tingkat kelulushidupan (Tabel 1) diperoleh dari pemeliharaan ikan nila salin selama 14 hari dengan perlakuan penambahan ekstrak bawang putih yang berbeda-beda pada pakan dan pengamatan salama 7 hari pasca penginfeksian bakteri V.harveyi. Nilai SR ikan nila salin yang tinggi terlihat pada perlakuan D (150 ppm) yaitu hingga $93,33 \pm 5,77$ dan setelah uji tantang menjadi $68,15 \pm 8,98$. Hal itu menjelaskan bahwa dengan penambahan ekstrak bawang putih pada pakan yang diberikan dapat meningkatkan kelulushidupan ikan nila salin. Hal tersebut terlihat berbeda nyata pada perlakuan A (0 ppm) terhadap perlakuan B (50 ppm), C (100 ppm) dan D (150 ppm), dimana pada perlakuan A (0 ppm) pasca uji tantang nilai SR yang diperoleh adalah 48,15\%. Gambar pola kematian dan kelushidupan ikan nila salin (O.niloticus) tersaji pada Gambar 2

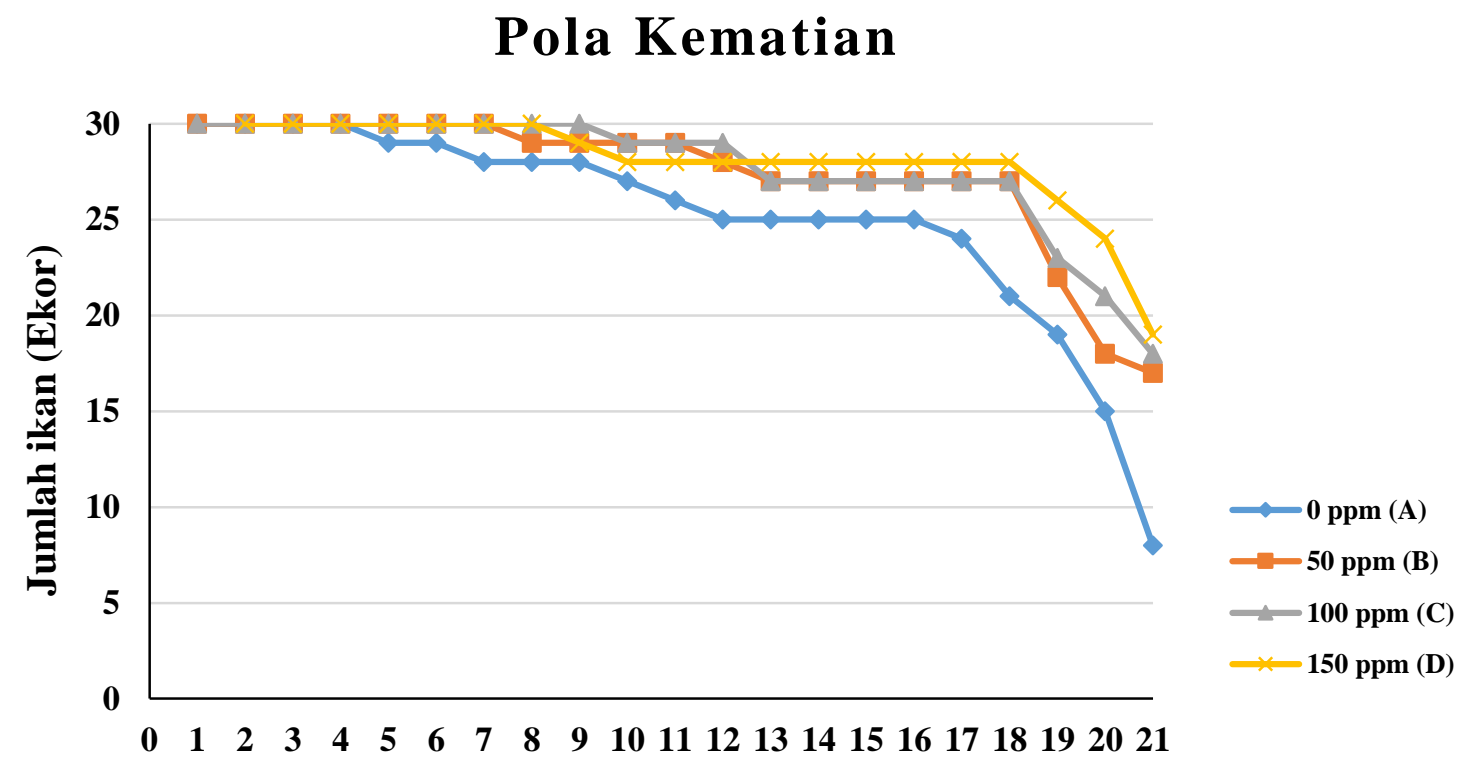

Hari ke-
Gambar 2. Pola kematian dan kelushidupan Ikan Nila Salin (O.niloticus)

Dari hasil (Gambar 2.), tingkat kelulushidupan ikan nila salin dari awal pemeliharaan sampai uji tantang dengan penginfeksian menggunakan bakteri V.harveyi mengalami penurunan persentase kelulushidupan yang drastis pada perlakuan A $(0 \mathrm{ppm})$ disbanding dengan perlakuan $\mathrm{B}(50 \mathrm{ppm}), \mathrm{C}(100 \mathrm{ppm})$ dan nilai persentase kelulushidupan tertinggi pada perlakuan D $(150 \mathrm{ppm})$. Pola kematian terendah terlihat pada ikan nila salin yang diberi perlakuan tanpa penambahan ekstrak bawang putih pada pakan. Berbeda dengan ikan nila salin yang diberi perlakuan dengan penambahan ekstrak bawang putih $150 \mathrm{ppm}$ dapat menekan angka kematian baik selama pemeliharaan maupun selama uji tantang dengan penginfeksian menggunakan bakteri V.harveyi. Ikan nila salin yang dipelihara selama 21 hari dilakukan penginfeksian bakteri V.harveyi pada hari ke-14. Diagram Kelulushidupan Ikan nila salin (O.niloticus) pasca uji tantang tersaji pada Gambar 3. 


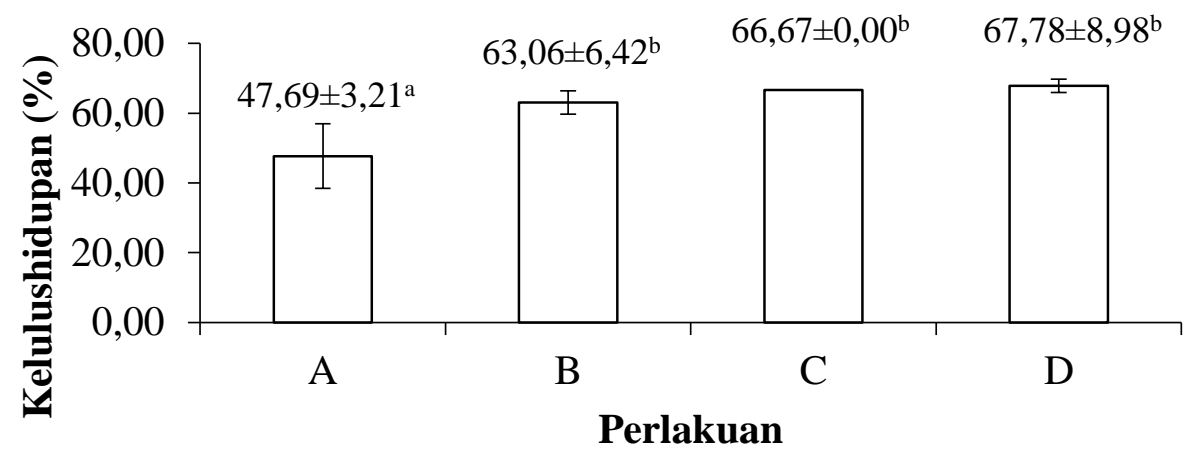

Gambar 3. Diagram Kelulushidupan Ikan Nila Salin (O.niloticus) Pasca Uji Tantang

Dari hasil (Gambar 3) juga dapat dilihat nilai kelulushidupan ikan nila salin pasca dilakukan uji tantang mengalami penurunan yang drastis, dimana tingkat kelulushidupan yang terting gi terlihat pada perlakuan $\mathrm{D}$ (150 ppm) yang hanya mendapatkan nilai kelulushidupan sebesar $67,78 \pm 8,98$, diikuti oleh perlakuan $C(66,67 \pm 0,00)$ dan B yaitu $(63,06 \pm 6,42)$ dan terendah terlihat pada perlakuan A $(47,69 \pm 3,21)$. Dari hasil tersebut dapat dilihat bahwa selama 7 hari pengamtan pasca uji tantang, ikan nila salin yag diberi pakan tanpa penambahan ekstrak bawang putih (A $0 \mathrm{ppm}$ ) memiliki tingkat kematian yang paling tinggi.

\section{Pengamatan Gejala Klinis}

Pengamatan gejala klinis tingkah laku ikan nila salin, diperoleh ciri-ciri morfologi ikan nila salin yang terserang bakteri V.harveyi yang tersaji pada Tabel 2.

Tabel 2. Hasil Uji Gejala Klinis Morfologi Ikan Nila Salin (O.niloticus)

\begin{tabular}{|c|c|c|c|}
\hline No & $\begin{array}{l}\text { Gejala klinis morfologi ikan nila salin } \\
\text { yang terinfeksi V.harveyi }\end{array}$ & $\begin{array}{l}\text { Hasil penelitian } \\
\text { (Perlakuan) }\end{array}$ & $\begin{array}{c}\text { Pustaka } \\
\text { (Gejala Klinis) }\end{array}$ \\
\hline 1 & Terdapat Luka & + & Ikan yang terinfeksi V.harveyi adalah \\
\hline 2 & $\begin{array}{l}\text { Warna tubuh/overculum } \\
\text { gelap/menghitam }\end{array}$ & + & $\begin{array}{l}\text { anorexia atau hilang nafsu makan } \\
\text { yang disertai dengan warna tubuh }\end{array}$ \\
\hline 3 & Produksi lendir berlebih & + & $\begin{array}{l}\text { menghitam). Ikan yang terinfeksi } \\
\text { juga akan mengalami kehilangan } \\
\text { keseimbangan dan menunjukkan }\end{array}$ \\
\hline 4 & Sirip punggung dan ekor gripis & + & $\begin{array}{l}\text { perilaku berenang yang tidak } \\
\text { normal. (Tendencia dan Lavilla- } \\
\text { Pitogo, 2004.* }\end{array}$ \\
\hline
\end{tabular}

Keterangan : *Tendencia dan Lavilla-Pitogo (2004) penyakit infeksi pada budidaya laut di Indonesia

Dari hasil (Tabel 2), ikan nila salin yang terserang baketri $V$. harveyi memiliki gejala klinis secara morfologi yaitu ikan terdapat luka pada bagian punggung, sirip dan ekor terlihat geripis. Pada saat ikan mati dapat dilihat overculum menghitam dan produksi lender berlebih. Hasil gejala klinis tingkah laku ikan juga diamati, dan diperoleh hasil bahwa ikan nila salin kehilangan nafsu makan, terlihat lemas dan ikan berenang dengan tidak normal yaitu berenang miring.

\section{Kualitas air}

Hasil monitoring kualitas air selama penelitian tersaji pada Tabel 4.

Tabel 4. Hasil Pengukuan Parameter Kualitas Air pada Media Pemeliharaan Ikan Nila Salin (O.niloticus) Selama Penelitian

\begin{tabular}{ccccc}
\hline Perlakuan & \multicolumn{4}{c}{ Rata-rata } \\
\cline { 2 - 5 } & DO $(\mathrm{mg} / \mathrm{L})$ & Salinitas $(\mathrm{ppt})$ & Suhu $\left({ }^{\circ} \mathrm{C}\right)$ & $\mathrm{pH}$ \\
\hline A & $2,9-3,3$ & 10 & $25-28$ & $6,7-7,4$ \\
B & $2,9-3,1$ & 10 & $26-28$ & $6,8-7,3$ \\
C & $3-3,3$ & 10 & $27-29$ & $6,8-7,3$ \\
D & $2,9-3,1$ & 10 & $26-29$ & $6,7-7,3$ \\
Pustaka & $\geq 3^{\mathrm{a}}$ & $10-20 \mathrm{ppt}^{\mathrm{a}}$ & $25-32^{\mathrm{a}}$ & $6,5-8,5^{\mathrm{a}}$ \\
(Kelayakan) & & & & \\
\hline
\end{tabular}

Keterangan: ${ }^{a}$ SNI 7550:2009 
Berdasarkan hasil (Tabel 4) monitoring kualitas air yang dilakukan selama penelitian dapat dilihat bahwa salinitas dijaga untuk selalu berada pada nilai 10 ppt. Kadar salinitas air pemeliharaan dimulai dengan persiapan air pada bak stok air didalam bak fiber. Hasil pengukuran parameter kualitas air menunjukkan bahwa kualitas air yang diukur masih layak berdasarkan pustaka untuk budidaya ikan nila salin (O.niloticus).

\section{Pembahasan}

\section{Total Leukosit}

Berdasarkan penelitian tentang perhitungan total leukosit yang telah dilakukan, diperoleh hasil yaitu total leukosit yang tinggi dilihat pada perlakuan D yaitu pakan dengan konsentrasi $150 \mathrm{ppm}$ dengan total leukosit adalah

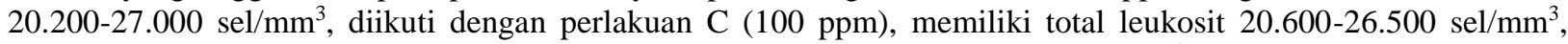
sedangkan pada perlakuan B (50 ppm) memiliki total leukosit $20.600-25.000 \mathrm{sel} / \mathrm{mm}^{3}$, dan total leukosit terendah terlihat pada perlakuan A (0 ppm) yaitu 20.200-21.600 sel $/ \mathrm{mm}^{3}$. Hal tersebut menunjukkan bahwa penambahan ekstrak bawang putih dapat memicu pertumbuhan sel leukosit pada ikan nila salin yang diperlihara. Peningkatan jumlah sel leukosit pada ikan nila salin akan meningkatkan nilai kelulushidupan ikan nila salin yang diinfeksi dengan bakteri $V$. harveyi. Sel leukosit dalam darah memiliki peranan terhadap kekebalan seluler dari ikan, sehingga ikan nila salin memiliki daya tahan tubuh terhadap serangan patogen berbahaya yang dapat menyebabkan kematian pada ikan nila salin. Jumlah total leukosit yang diperoleh yang tertinggi terlihat pada perlakuan D (150 ppm) yaitu 20.200$27.000 \mathrm{sel} / \mathrm{mm}^{3}$. Menurut Lagler et al. (1977) kisaran normal leukosit ikan nila $20.000 \mathrm{sel} / \mathrm{mm}^{3}-150.000 \mathrm{sel} / \mathrm{mm}^{3}$. Faktor-faktor yang mempengaruhi jumlah leukosit adalah kondisi dan kesehatan tubuh ikan. Leukosit merupakan sel darah yang berperan dalam sistem kekebalan tubuh. Leukosit membantu membersihkan tubuh dari benda asing, termasuk invasi patogen melalui sistem tanggap kebal dan respon lainnya. Ikan yang sakit akan menghasilkan banyak leukosit untuk memfagosit bakteri dan mensintesa antibodi (Moyle and Cech 2004).

Berdasarkan hasil penelitian ini, pertumbuhan sel leukosit dalam darah ikan dapat memicu tingkat kelulushidupan ikan nila salin yang dipelihara terhadap serangan penyakit, sehingga dapat meningkatkan nila SR ikan nila salin yang dipelihara. Hal itu terlihat saat ikan nila salin diuji tantang dengan penginfeksian bakteri V.harveyi pada ikan nila salin yang dipelihara. Hasil ini menunjukkan bahwa dengan meningkatnya total leukosit pada ikan nila salin, sehingga ikan yang diinfeksi oleh bakteri V.harveyi memliki angka kematian yang kecil. Perlakuan D (150 ppm) menunjukkan nila SR tertinggi yaitu hingga 67,78\% dan juga dengan nilai total leukosit tertinggi pada perlakuan D (150 ppm) yaitu 48.300-56.600 sel/ $\mathrm{mm}^{3}$. Berdasarkan fungsi dari sel leukosit didalam tubuh, penambahan ekstrak bawang putih ke pakan ikan nila salin dapat meningkatkan sel darah putih pada tubuh ikan, sehingga ikan nila salin yang dipelihara memiliki daya tahan tubuh tinggi terhadap serangan berbagai macam penyakit. Leukosit memiliki peranan penting terhadap serangan patogen berbahaya dari lingkungan budidaya ikan, jika total leukosit pada tubuh ikan nila salin yang dipelihara tinggi, maka ikan nila salin tersebut akan memiliki sistem imun yang baik terhadap serangan bakteri yang diberikan. Hal ini diperkuat oleh Lengka (2013) yang menyatakan bahwa jumlah leukosit yang ada pada suatu jenis ikan tertentu dapat berubah sesuai dengan tingkat kesehatan ikan yang bersangkutan. Apabila ikan terinfeksi oleh suatu bakteri patogen tertentu maka yang akan terjadi selanjutnya pada ikan tersebut adalah meningkatnya jumlah total leukosit atau menurunnya jumlah leukosit. Ikan yang kekurangan jumlah leukosit menjauhi batas normalnya akan menderita penyakit leucopenia.

\section{Kelulushidupan (SR)}

Tingkat kelulushidupan ikan nila salin yang dipelihara selama penelitian memiliki perbedaan pada setiap perlakuan. Tingkat kematian tertinggi terlihat pada perlakuan A $(0 \mathrm{ppm})$, dimana ikan yang dipelihara mati sebanyak 22 ekor dari total awal ikan yang dipelihara sebanyak 30 ekor. Berbeda hal dengan perakuan D (150 ppm), dimana dapat meningkatkan tingkat kelulushidupan dari ikan yang dipelihara yaitu dari total ikan yang dipelihara 30 ekor dan yang mati hanya 11 ekor. Hal itu terbukti dengan panambahan ekstrak bawang putih pada pakan dapat meningkatkan sel leukosit dalam darah ikan, sehingga sel leukosit tersebut dapat melawan serangan infeksi bakteri yang diberikan. Menurut Mulyani (2014) menaytakan bahwa .nilai perbandingan antara jumlah organisme saat akhir pemeliharaan dengan jumlah awal saat penebaran dan dinyatakan dalam bentuk persen disebut dengan kelulushidupan. Semakin besar jumlah ikan yang hidup di akhir maka semakin besar juga nilai kelulushidupannya. Kelulushidupan merupakan parameter keberhasilan suatu kegiatan budidaya. Parameter ini digunakan untuk mengukur seberapa jauh kemampuan ikan nila salin (O.niloticus) untuk bertahan hidup.

Pengamatan tingkat kelulushidupan dilakukan selama 21 hari dengan 2 tahap pengamatan, tahap pertama ikan nila salin dipelihara selama 14 hari dengan pakan mengandung ekstrak bawang putih dan tahap kedua pasca uji tantang selama 7 hari, untuk mengetahui jumlah ikan nila salin yang hidup diakhir penelitian. Tahap pertama ikan nila salin dipelihara selama 14 hari dengan total ikan 10 ekor/akuarium, dan pengamatan SR dilakukan setiap hari untuk mengetahui apakah ikan nila salin ada yang mati. Hasil yang diperoleh pada ikan nila salin yang

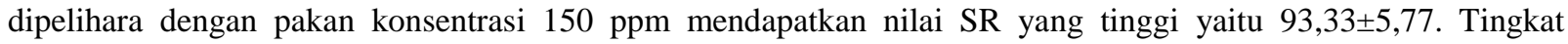
kelulushidupan ikan nila salin yang dipelihara pada perlakuan B (50 ppm) dan C (100 ppm), memiliki nilai SR yaitu 


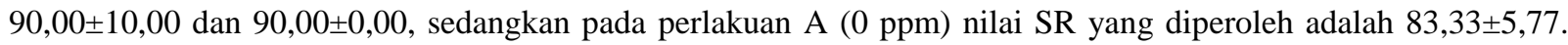
Nilai SR ikan nila salin yang diperlihara memiliki nilai SR diatas rata-rata $90 \%$ dan terendah pada perlakuan A (0 ppm) yaitu 83,33\%. Hal ini juga menunjukkan bahwa tingkat kelangsungan hidup ikan nila salin selama pemeliharaan tergolong baik. Hal ini dinyatakan oleh Mulyani (2014) bahwa tingkat kelangsungan $\geq 50 \%$ tergolong baik, kelangsungan hidup 30-50\% sedang dan kurang dari 30\% tidak baik. Kelangsungan hidup ikan sangat bergantung pada daya adaptasi ikan terhadap makanan dan lingkungan, status kesehatan ikan, padat tebar, dan kualitas air yang cukup mendukung pertumbuhan.

Tingkat kelulushidupan ikan nila salin juga diamati setelah proses penginfeksian atau dilakukan uji tantang dengan penginfeksian bakteri V.harveyi. Dimana setelah diinfeksi bakteri V.harveyi, ikan nila salin selanjutnya diamati dan dipelihara selama 7 hari dan mencatat gejala klinis dan jumlah kematian ikan. Hasil yang diperoleh setelah penginfeksian dengan bakteri V.harveyi menunjukkan penurunan nila SR pada ikan yang dipelihara, pada perlakuan D (150 ppm) nila SR yang diperoleh yaitu 67,78\%, perlakuan C (100 ppm) memperoleh hasil nilai SR yaitu $66,67 \%$. Nilai SR pada perlakuan B (50 ppm), setelah diinfeksi oleh bakteri V.harveyi memperoleh nilai SR yaitu $63,06 \%$ dan nila SR terendah terlihat pada perlakuan A (0 ppm) yaitu 47,69\%. Hal ini menunjukkan bahwa perlakuan A $(0 \mathrm{ppm})$ dalam 7 hari pemeliharaan pasca penginfeksian memiliki persentase kematian yang tinggi yaitu sebesar $60 \%$ dan terendah pada perlakuan D (150 ppm) yaitu sebesar 33\%. Hal itu menunjukkan bahwa kandungan bawang putih yang ditambahkan pada pakan dapat menekan angka kematian akibat infeksi bakteri V.harveyi. Banyak sekali zat yang terkandung didalam bawang putih sebagai antibakteri, salah satu kandungan bawang putih yang dapat mencegah infeksi bakteri adalah allicin. Hal ini diperkuat oleh Lengka (2013), yang menyatakan bahwa allicin merupakan salah satu zat aktif yang dapat membunuh patogen (bersifat antibakteri) seperti bakteri. Sedangkan alicin yang terkandung dalam bawang putih secara signifikan dapat meningkatkan sel leuokist dalam darah ikan, sehingga bawang putih dapat digunakan sebagai imunostimulan yang efesien.

Pada penelitian ini, selain tingkat kelulushidupan, ikan nila salin juga diamati gejala klinis yang disebabkan infeksi bakteri V.harveyi. Ikan nila salin yang terserang penyakit bakteri V.harveyi akan menyebabkan kematian. Bakteri V.harveyi dapat menyerang ikan yang dihidup pada air bersalinitas, dan bakteri V.harveyi tergolong pada jenis bakteri Gram negatif. Ikan nila salin yang diinfeksi dengan bakteri V.harveyi, baru 2 hari pemeliharaan sudah menunjukkant gejala klinis yang disebebkan bakteri V.harveyi. Gejala klinis yang diperoleh yaitu pada bagian tubuh terlihat seperti luka dan pada bagian sirip dan ekor yang terlihat geripis. Ikan nila salin yang diinfeksi bakteri V.harveyi juga terlihat berenang lebih lambat, dan menurunnya nafsu makan. Ikan juga terlihat sering muncul kepermukaan untuk mengambil oksigen. Hal ini merupakan ciri-ciri ikan yang terinfeksi bakteri V.harveyi, dimana bakteri ini lebih sering dikenal dengan panyakit vibriosis, dan sangat berbahaya bagi kultivan budidaya khususnya buidaya ikan air bersalinitas. Hal ini diperkuat oleh Desrina et al., (2006) yang menyatakan bahwa, gejala klinis awal yang terlihat adalah nafsu makan berkurang, lesu, berenang miring, ginjal pucat. Ikan yang sakit dan mati menunjukkan gejala ginjal pucat, borok pada tubuh, dan mulut merah. Luka pada tubuh terlihat setelah 6 hari pasca infeksi, yang makin lama makin besar dan menjadi borok berdiameter $2 \mathrm{~cm}$.

Berdasarkan hasil uji tantang yang dilakukan, ikan nila salin yang tanpa diberi perlakuan atau pakan tanpa campuran ekstrak bawang putih lebih rentan terhadap serangan bakteri V.harveyi dan lebih cepat mati. Hal itu berbeda dengan ikan nila salin yang diberi pakan dengan campuran ekstrak bawang putih. Hasil yang menunjukkan bahwa pakan yang mengandung ekstrak bawang putih yang tinggi yakni 150 ppm dapat menekan angka kematian pada ikan nila salin. Hal itu dapat dilihat bahwa nila SR ikan yang pada perlakuan D (150 ppm) adalah 67,78\%. Hal itu menunjukkan bahwa ekstrak bawang putih yang dicampurkan ke pakan berpengaruh terhadap jumlah leukosit dalam darah ikan sehingga berpengaruh terhadap tingkat kelulushidupan ikan nila salin yang terserang bakteri V.harveyi. Terdapat kandungan bawang putih yang dapat memicu pertumbuhan sel leukosit dalam darah ikan, yaitu zat allicin. Hal itu diperkuat oleh Prihandani (2015) yang menyatakan bahwa zat bioaktif yang berperan sebagai antibakteri dalam bawang putih adalah allicin yang mudah menguap (volatil) dengan kandungan sulfur. Komponen bioaktif lainnya adalah dialildisulfida, dan dialiltrisulda yang juga memiliki aktivitas antibakteri. Aktivitas antibakteri bawang putih dapat mengendalikan bakteri-bakteri patogen, baik Gram negatif maupun positif .

\section{Kualitas air}

Kualitas air berpengaruh terhadap kelulushidupan ikan nila salin, maka dari itu perlu dilakukan monitoring kualitas air, agar kualitas air terjaga dan tidak menyebabkan ikan mati. Kualitas air dikontrol setiap hari, dan hasil pengamatan kualitas air meliputi suhu, DO, pH dan salinitas. Hasil pengamatan DO yang diperoleh selama proses pemeliharaan ikan nila salin yaitu berkisar 2,9-3,3; $\mathrm{pH}$ berkisar 7,3-7,5; suhu berkisar $25,9-27,1^{\circ} \mathrm{C}$; dan salinitas 10 ppt. Salinitas air pada pemeliharaan ikan nila salin tetap dijaga 10 ppt karena apabila salinitas air tidak stabil maka akan menyebabkan ikan nila salin yang dipelihara akan mengalami stres bahkan kematian. Kualitas air selama penelitian tergolong baik, hal ini diperkuat oleh Effendi (2003), untuk kelayakan kelangsungan dan pertumbuhan ikan nila salin adalah suhu 27-30 0C, p H 7-8,5, salinitas $10-20$ ppt, DO 6-8, amoniak 0,1, kecerahan $25-30 \mathrm{~cm}$. Menurut Prayudi (2015), yang menyatakan bahwa kualitas air merupakan salah satu faktor penting yang 
berpengaruh pada pertumbuhan dan keberlangsungan hidup ikan. Adapun data kualitas air yang diukur dalam penelitian yakni Suhu, derajat keasaman $(\mathrm{pH})$ dan oksigen terlarut (DO).

\section{KESIMPULAN DAN SARAN Kesimpulan}

Berdasarkan hasil penelitian yang telah dilakuan, maka kesimpulan yang dapat diberikan adalah

1. Penambahan ekstrak bawang putih berpengaruh terhadap tingkat pertumbuhan leukosit yaitu yang tertinggi pada perlakuan D (150 ppm) sebanyak 20.200-27.000 sel/mm3, sehingga berpengaruh terhadap tingkat kelulushidupan ikan nila salin (O. niloticus) yaitu 93\% dan pasca uji tantang dengan penginfeksian bakteri V.harveyi menjadi $67 \%$. 2. Konsentrasi terbaik dan masih toleran terhadap tubuh ikan nila salin (O.niloticus) adalah pada perlakuan D (150 ppm) dimana nilai kelulushidupan ikan yang diinfeksi dengan bakteri $V$. harveyi yaitu $67 \%$, diikuti dengan perlakuan C (100 ppm) yaitu 66\% dan B (50 ppm) yaitu 62\% dan terendah pada perlakuan A (0 ppm) yaitu 48\%.

\section{Saran}

Berdasarkan penelitian yang telah dilakukan, saran yang dapat disampaikan perlu dilakukan penelitian lanjutan dengan menggunakan konsentrasi yang lebih tinggi untuk mengetahui konsentrasi optimum penambahan ekstrak bawang putih terhadap tingkat pencegahan infeksi bakteri V.harveyi dan kelulushidupan ikann nila (O. niloticus).

\section{DAFTAR PUSTAKA}

Agustinus, F., Widanarni, dan J. Ekasari. 2010. Kelimpahan dan Keragaman Jenis Bakteri dalam Air dan Parameter Imunitas Ikan Nila Merah yang Dipelihara dalam Sistem Bioflok dengan Kepadatan Ikan Yang Berbeda (25 ekor $/ \mathrm{m}^{3}, 50 \mathrm{ekor} / \mathrm{m}^{3}$, dan $\left.100 \mathrm{ekor} / \mathrm{m}^{3}\right)$. Jurnal Akuakultur Indonesia. 9(2): 157-167.

Aliah, R. S. 2017. Rekayasa Produksi Ikan Nila Salin Untuk Perairan Payau di Wilayah Pesisir. Jurnal Rekayasa Lingkungan. 10(1): 17-24.

Aniputri, F. D., J. Hutabarat dan Subandiyono. 2014. Pengaruh Ekstrak Bawang Putih (Allium sativum) terhadap Tingkat Pencegahan Infeksi Bakteri Aeromonas hydrophila dan Kelulushidupan Ikan Nila (Oreochromis niloticus). Journal of Aquaculture Management and Technology. 3(2): 1-10.

Ardita, N., A. Budiharjo, A, dan S. L. A. Sari. 2015. Pertumbuhan dan Rasio Konversi Pakan Ikan Nila (Oreochromis niloticus) dengan Penambahan Prebiotik. Jurnal Bioteknologi. 12(1): 16-21.

Aquarista, F., Iskandar dan U. Subhan. 2012. Pemberian Probiotik dengan Carrier Zeolit pada Pembesaran Ikan Lele Dumbo (Clarias gariepinus). Jurnal Ilmiah Perikanan dan Kelautan. 3(4): 136-137.

Bintari. N. W. D, R. Kawuri, dan A. A. G. R. Dalem. 2016. Identifikasi Bakteri Vibrio Penyebab Vibriosis Pada Larva Udang Galah (Macrobrachium rosenbergi(de man)). Jurnal Biologi. 20(2) : 53-63

Bokau. R. JM, Rakhmawati, dan Nur Indaryanti. 2014. Optimasi Pengelolaan Pakan Untuk Meningkatkan Pertumbuhan Ikan Nila Gesit Di Bak Terpal. Pengembangan Teknologi Pertanian. 585-592

Desrina, A. Taslihan, Ambariyanto, dan S. Suryaningrum. 2006. Uji Keganasan Bakteri Vibrio pada Ikan Kerapu Macan (Epinephelus fuscoguttatus). Ilmu Kelautan. 11 (3) : 119 - 125

Effendi, H. 2003. Telaah kualitas air. Kanisius. Yogyakarta.

Hadi, S. 1985. Metodologi Research Jilid 4. Yogyakarta: Yayasan Penerbit Fakultas Psikologi UGM. 88 hlm.

Hartika, R., Mustahal dan A. N. Putra. 2014. Gambaran Darah Ikan Nila (Oreochromis Niloticus) dengan Penambahan Dosis Prebiotik yang Berbeda dalam Pakan. Jurnal Perikanan dan Kelautan. 4(4): 259-267.

Indriani. A. D, S. B. Prayitno, dan Sarjito. 2014. Penggunaan Ekstrak Jahe Merah (Zingiber Officinale Var. Rubrum) Sebagai Alternatif Pengobatan Ikan Nila (Oreochromis Niloticus) Yang Diinfeksi Bakteri Aeromonas Hydrophila. Journal Of Aquaculture Management And Technology 3(3):58-65

Jalaludin. 2014. Pengaruh Salinitas terhadap Fekunditas Fungsional, Daya Tetas Telur dan Benih Ikan Nila Salin (Oreochromis niloticus Linn). Jurnal Manajemen Perikanan dan Kelautan. 1(2): 17-32.

Jegede, T. 2012. Effect of Garlic (Allium sativum) on Growth, Nutrient Utilization, Resistance and Survival of Tilapia zillii (Gervais 1852) Fingerlings. Journal of Agricultural Science. 4(2):269-274.

Kusumaningrum. H. P, Kusdiyantini. E, dan Sri Pujiyanto. 2015. Tingkat Cemaran Mikrobia pada Tanaman Biofarmaka Curcuma domestica setelah Proses Pengeringan. 128-133.

Lagler KF, Bardach JE, RR Miller, Passino DRM. 1977. Ichthyology. New York-London: John Willey and Sons. Inc. $506 \mathrm{hlm}$.

Lengka, K., H. Manoppo dan M. E. F. Kolopita. 2013. Peningkatan Respon Imun Non Spesik Ikan Mas (Cyprinus carpio L) Melalui Pemberian Bawang Putih (Allium Sativum). Jurnal Budidaya Perairan. 1(2): 21-28.

Lingga, E. M dan M. M. Rustama. 2005. Uji Aktivitas Antibakteri Dari Ekstrak Air Dan Etanol Bawang Putih (Allium Sativum L.) Terhadap Bakteri Gram Negatif Dan Gram Positif Yang Diisolasi Dari Udang Dogol (Metapenaeus Monoceros), Udang lobster (Panulirus Sp), Dan Udang Rebon (Mysis Dan Acetes). 
Lukistyowati, I., Windarti, Morina, A. Isnansetyo, dan Kurniasih. 2008. Efektivitas Ekstrak Bawang Putih (Allium Sativum) Untuk Mencegah dan Mengobati Motile Aeromonas Septicemia (Mas) Pada Ikan Mas (Cyprinus carpio). Jurnal Perikanan. X(1): 11-19.

Majewski M. 2014. Allium sativum: Facts and Myths Regarding Human Health. J Natl Ins Public Health. 65 (1): 18.

Mardiana dan S. Budi. 2017. Respon Immun Ikan Nila Oreochromis Niloticus dengan Pemberian Xanton yang Diekstraksi dari Kulit Buah Manggis Garcinia Mangostana. 6 (1).

Maryono dan A. Sundana. 2002. Teknik Pencegahan dan Pengobatan Penyakit Bercak Merah Pada Ikan Air Tawar yang Disebabkan Oleh Bakteri Aeromonas hydrophila. Buletin Teknik Pertanian., 7(1): 33-36.

Mikaili P, Maadirad S, Moloudizargari M. 2013. Therapeutic uses and pharmacological properties of garlic, shallot, and their biologically active compounds. Iran J Basic Med Sci. 16 (10): 1031-1048.

Moyle P.B. dan Jr. J.J. Cech 2004. Fishes. An Introduction to Ichthyology. 5th ed. USA: Prentice Hall, Inc.

Mulyani, Y. S., Yulisman dan M. Fitrani. 2014. Pertumbuhan dan Efisiensi Pakan Ikan Nila (Oreochromis niloticus) yang Dipuasakan Secara Periodik. Jurnal Akuakultur Rawa Indonesia. 2(1): 1-12.

Muslim, M. P. Hotly dan H. Widjajanti. 2009. Penggunaan Ekstrak Bawang Putih (Allium Sativum) Untuk Mengobati Benih Ikan Patin Siam (Pangasius Hypophthalmus) yang Diinfeksi Bakteri Aeromonas Hydrophylla. Jurnal Akuakultur Indonesia. 8(1): 91-100

Nitimulyo, K. H., A. Isnansetyo, Triyanto, I. Istiqomah dan M. Murdjani. 2005. Isolasi, Identifikasi dan Karakterisasi Vibrio Spp. Patogen Penyebab Vibriosis pada Kerapu di Balai Budidaya Air Payau Situbondo. Jurnal Perikanan. VII(2): 80-94.

Novriadi, R. 2014. Penyakit Ikan Air Laut di Indonesia. Kementerian Kelautan dan Perikanan, Direktorat Jenderal Perikanan Budidaya, Direktorat Kesehatan Ikan dan Lingkungan. 28

Prihandani. S. S, M. Poeloengan, S. M. Noor, dan Andriani. 2013. Uji Daya Antibakteri Bawang Putih (Allium Sativum L.) Terhadap Bakteri Staphylococcus aureus, Escherichia coli, Salmonella typhimurium dan Pseudomonas aeruginosa Dalam Meningkatkan Keamanan Pangan.

Puspitasari. A. D, dan L. S. Proyogo. 2014. Perbandingan Metode Ekstraksi Maserasi Dan Sokletasi Terhadap Kadar Fenolik Total Ekstrak Etanol Daun Kersen (Muntingia Calabura). Jurnal Ilmiah Cendekia Eksakta.

Rantetondok. A. 2002. Pengaruh Immunostimulan $\beta$-glukan dan Lipopolisakarida terhadap Respons Imun dan Sintasan Udang Windu (Panaeus monodon fabricius). Disertasi. Makassar. Program Pascasarjana Universitas Hasaniddin.

Sari. D. R, S. B. Prayitno, dan Sarjito. 2016. Pengaruh Perendaman Ekstrak Bawang Putih (Allium Sativum) Terhadap Kelulushidupan Dan Histologi Ginjal Ikan Lele (Clarias Gariepinus) Yang Diinfeksi Bakteri "Edwardsiella Tarda". Journal of Aquaculture Management and Technology. 3(4) : 126-133.

Sarjito. 2010. Aplikasi Biomolekuler untuk Deteksi Agensia Penyebab Vibriosis pada Ikan Kerapu dan Potensi Bakteri Sponge sebagai Anti Vibriosis. [Disertasi]. Program Pasca Sarjana, Universitas Diponegoro, Semarang.

Sarker, D.,Satyajit., Latif, Z., \& Gray, I.A., 2005, Natural Products Isolation, 2nd Ed, 283- 285, New Jersey, Humana Press.

Saptiani. G, S. B. Prayitno dan, Sutrisno Anggoro. 2012. Aktivitas Antibakteri Ekstrak Jeruju (Acanthus ilicifolius) terhadap Pertumbuhan Vibrio harveyi Secara in vitro. Jurnal Veteriner. 13(3) : 257-262

Saulnier, D., P. Haffner, C. Goarant, P Levy, and D. Ansquer, 2000. Eksperimental Infection Models for Shrimp Vibriosis Studies: a Review. Aquaculture. 191:133-144.

Soraya. C, Chismirina. S, dan Rizki Novita. 2018. Pengaruh Perasan Bawang Putih (Allium Sativum L.) Sebagai Bahan Irigasi Saluran Akar Dalam Menghambat Pertumbuhan Enterococcus faecalis Secara In Vitro. Cakradonya Dent J. 10(1): 1-9

SNI. 2009. Produksi Ikan Nila (Oreochromis niloticus Bleeker) Kelas Pembesaran di Kolam Air Tenang. 01-75502009.

Wahjuningrum, D., E,H. Solikhah., T. Budiardi dan M. Setiawati. 2010. Pengendalian Infeksi Aeromonas hydrophila Pada Ikan Lele Dumbo (Clarias sp.) dengan Campuran Meniran (Phyllanthus niruri) dan Bawang Putih (Allium sativum) Dalam Pakan. J. Akuakultur Indonesia., 9 (2): 93-103.

Wahjuningrum, Fauziah. R. N. Sukenda, dan Ranta. 2015. Campuran Tepung Bawang Putih - Meniran Untuk Pencegahan Infeksi Streptococcus agalactiae pada Ikan Nila. Jurnal Akuakultur Indonesia. 12(1): 79-89.

Widanarni, D. Meha, S. Nuryati, Sukenda, dan A. Suwanto. 2004. Uji Patogenisitas Vibrio Harveyi Pada Larva Udang Windu Menggunakan Resisten Rifampisin Sebagai Penanda Molekuler. Jurnal Akuakultur Indonesia, 3(3): 23-27

Yanuhar, U. 2012. Pengaruh Pemberian Bahan Aktif Ekstrak Nannochloropsis oculata terhadap Kadar Radikal Bebas pada Ikan Kerapu Tikus (Cromileptes altivelis) yang Terinfeksi Bakteri Vibrio alginolyticus. Jurnal Ilmiah Perikanan dan Ilmu Kelautan. 1 (2) : 185-191 